\title{
ASUHAN KEPERAWATAN BAYI PREMATUR MENGUNAKAN MODEL KEPERAWATAN KONSERVASI ENERGY MYRA LEVINE: SEBUAH STUDY KASUS
}

\author{
Herlina \\ Departemen Keperawatan Anak, Fakultas Ilmu - Ilmu Kesehatan, Universitas \\ Pembangunan Nasional "Veteran", Jakarta 12450, Indonesia \\ E-mail: herlinamail@yahoo.co,id
}

\begin{abstract}
Abstrak
Bayi prematur merupakan manusia yang rentan gagal beradaptasi karena faktor imaturitas. Faktor imaturitas pernafasan dan kelemahan otot oro-motor menjadi tantangan bayi prematur untuk memenuhi kebutuhan energi. Konservasi energi membantu bayi mencapai integritas struktur yang membantu bayi tumbuh dan berkembang sehingga tercapai integritas personal dan sosial. Penelitian ini bertujuan menganalisis aplikasi Model Keperawatan Konservasi Energy Myra E Levine pada bayi prematur. Penelitian ini merupakan penelitian deskriptif dengan study kasus pada empat bayi prematur yang memiliki kondisi fisiologis stabil ditandai dengan tidak menggunakan alat bantu pernafasan. Hasil penelitian menunjukkan tropicognosis pada keempat kasus adalah gangguan pola nafas, gangguan termoregulasi, resiko ketidakefektifan perfusi jaringan, resiko infeksi (lanjut), resiko cedera internal, nutrisi kurang dari kebutuhan tubuh, dan gangguan proses keluarga. Evaluasi keperawatan selama 2 minggu menunjukkan pola nafas dan termoregulasi efektif, infeksi lanjut dan cedera internal tidak terjadi, nutrisi adekuat. Peneliti menyarankan mengaplikasikan Teori Keperawatan Konservasi Energy Myra E Levine pada bayi prematur.
\end{abstract}

Kata kunci: asuhan keperawatan, bayi prematur, konservasi energi, teori keperawatan

\begin{abstract}
Premature infants are vulnerable human beings fail to adapt because of immaturity. Immaturity of the respiratory and weakness of oro-motor muscle becomes a challenge prematur infants to meet demands of energy. Conservation of energy help babies achieve structural integrity to grow and develop in order to achieve personal and social integrity. The aims of this research is to analyze application of Nursing Model Conservation Energy Myra E Levine in premature infants. This study is a descriptive case study in four premature infants who have a stable physiological condition characterized by not using respirator. The results showed tropicognosis were breathing pattern disorders, impaired thermoregulation, risk of ineffective tissue perfusion, risk of infection (late), risk internal injuries, nutrition less than body requirements, and changes of the family process. Nursing Evaluation showed pattern of breath and thermoregulation were effective, further infections and internal injuries do not occur, adequate nutrition. Researcher suggest to apply Nursing Theory Conservation of Energy Myra E Levine in premature infants.
\end{abstract}

Keywords: nursing care, premature infants, energy conservation, nursing theory 


\section{Pendahuluan}

Bayi prematur memperoleh energi dari asupan nutrisi. Intake nutrisi bayi prematur dapat melalui enteral maupun parenteral. Intake enteral pada bayi prematur sangat tergantung dari usia gestasi bayi. Bayi prematur yang lahir pada usia gestasi kurang dari 34 minggu belum mempunyai reflek hisap yang baik sehingga memerlukan bantuan artifisial oro gastastric tube (OGT) untuk intake enteral. Bayi prematur dapat mengalami kesulitan menerima terapi nutrisi enteral karena terjadi intoleransi feeding (Amendolia, 2011). Penatalaksanaan feeding bertujuan untuk mencukupi kebutuhan energi bayi prematur. Kebutuhan energi bayi prematur berbeda dengan bayi aterm. Bayi prematur memerlukan energi yang lebih tinggi untuk tumbuh yaitu $110-135 \mathrm{kcal} / \mathrm{kg} /$ hari. Kalori dapat diperoleh dari intake protein, lemak, dan karbohidrat (CSPEN, 2013). Model keperawatan konservasi diperkenalkan oleh Myra Levine. Model keperawatan ini menganggap manusia adalah makhluk yang selalu beradaptasi dengan lingkungan secara konstan hingga tercapailah wholeness atau integritas. Lingkungan eksternal manusia selalu menantang lingkungan internal untuk beradaptasi. Bayi prematur merupakan manusia yang rentan gagal beradaptasi karenafaktor imaturitas. Lingkungan internal bayi memerlukan energi untuk bertahan hidup dan tumbuh. Faktor imaturitas pernafasan dan kelemahan otot oro-motor menjadi salah satu tantangan bayi prematur untuk memenuhi kebutuhan energi. Penatalaksanaan nutrisi membantu bayi mendapatkan energi yang cukup untuk bertahan hidup dan tumbuh. Konservasi energi membantu bayi mencapai integritas struktur. Integritas struktur membantu bayi tumbuh dan berkembang sehingga tercapai integritas personal dan integritas sosial (Alligood \& Tomey, 2006; Meleis, 2012; Brodsky \& Ouellette, 2008). Berdasarkan uraian tersebut, peneliti tertarik untuk menanalisis asuhan keperawatan 
pada bayi prematur yang mengalami masalah nutrisi dengan menggunakan pendekatan Model Keperawatan Konservasi Myra levine. Pendekatan asuhan keperawatan ini diharapkan dapat membantu bayi prematur untuk mencapai konservasi energi, integritas struktur, integritas personal dan integritas sosial.

\section{Metode Penelitian}

Penelitian ini merupakan penelitian deskriptif dengan menggunakan metode pendekatan study kasus. Sampel penelitian ini berjumlah 4 bayi prematur yang diambil menggunakan teknik purposive sampling.

Kriteria inklusi meliputi bayi lahir dengan usia gestasi $<37$ minggu, kondisi fisiologis stabil ditandai dengan tidak menggunakan alat bantu nafas. Kriteria ekslusi meliputi bayiprematur yang memiliki kelainan kongenital seperti penyakit jantung bawaan, atresia ani, labio-palato skizis, hidrosephalus dan enyakit berat lainnya.
Bayi diberikan asuhan keperawatan yang menggunakan pendekatan Model Keperawatan Konservasi Energy Myra Levine selama dua minggu kemudian dilakukan evaluasi.

\section{Hasil Penelitian}

\section{Kasus 1}

Bayi Ny"S" lahir prematur (Usia gestasi/UG 29 minggu, usia kronologis /UK 29+2) dengan RD ec HMD dd sepsis. Berat lahir (BL) 1460 gram, panjang badan (PB) $51 \mathrm{~cm}$, lingkar kepala (LK) $28 \mathrm{~cm}$, APGAR skor menit pertama 7 dan menit kelima 9, tampak retraksi dada dan nafas cuping hidung. Reflek menelan dan menghisap lemah. Usia 2 hari tampak kuning grade I-II skala Kreamer. Hasil laboratorium tanggal 1 April 2014: $\mathrm{Hb}$ 16,4gr/dl, Leukosit 13,21, IT ratio 0,006, CRP 0,4mg/L, dan albumin $3,54 \mathrm{~g} / \mathrm{dl} /$ Tatalaksana bayi "S" (1) fototerapi blind; (2) cairan dan nutrisi $90 \mathrm{ml} / \mathrm{kg} /$ hari $\quad(140 \mathrm{ml})$ ditambah 20\% karena fototerapi: PG2 (2,5gr) 4,4 $\mathrm{ml} / \mathrm{jam}$, IL20\%0,6 ml/jam, dan D 10\%+ 
Ca 0,9ml/jam; (3)bubble CPAP dengan $\mathrm{FiO}_{2} 21 \%$ dan peep 6

Tropicognosis yang muncul adalah: (1) Gangguan pola nafas, (2) Gangguan termoregulasi, (3) Resiko ketidakefektifan perfusi jaringan, (4) Resiko infeksi (lanjut), (5) Resiko cedera internal, (6) Nutrisi kurang dari kebutuhan tubuh, (7) Gangguan proses keluarga.

Intervensi keperawatan terdiri dari monitor pernafasan bayi (frekuensi, kedalaman, pola nafas, dan retraksi dada), monitor warna kulit bayi, rawat nasal septum, suction, kolaborasi dengan dokter untuk meyesuaikan seting bubble CPAP dengan pernafasan bayi, monitor suhu tubuh dan suhu akral bayi, menjaga lingkungan bayi tetap hangat (suhu inkubator, nest, kain/linen), hangatkan tangan dan alat-alat sebelum menyentuh bayi, pakaikan topi bila bayi keluar dari inkubator, ajarkan pada ibu tentang perawatan metode kanguru (PMK), kaji capilary refill time (CRT), kolaborasi resusitasi cairan, monitor saturasi oksigen dan frekuensi nadi, monitor hasil laboratorium, ajarkan kepada orang tua cara tanda penurunan perfusi jaringan bila bayi telah dirawat di rumah(akral dingin dan CRT memanjang), kaji reflek hisap dan menelan bayi, timbang berat badan bayi, libatkan keluarga dalam perawatan (ajarkan dan motivasi memerah ASI, berikan reward pada ibu), monitor toleransi minum bayi, monitor nilai albumin, kaji dan manfaatkan sumber daya keluarga untuk merawat bayi di rumah. Implementasi keperawatan menjaga suhu lingkungan bayi tetap hangat, menyesuaiakan $\mathrm{FiO}_{2}$ dan peep pada bubble CPAP dengan kondisi bayi, menimbang berat badan bayi, memberikan cairan dan nutrisi sesuai program, melibatkan keluarga dalam perawatan.

Evaluasi dilakukan setelah tindakan keperawatan selama 2 minggu. Pola nafas efektif, tidak ada retraksi, tidak ada desaturasi, weaning bubble CPAP pada usia 20 hari. Termoregulasi efektif 
ditandai dengan tidak ada instabilitas suhu. Infeksi lanjut tidak terjadi ditandai dengan kultur darah steril pada hari kelima, procalsitonin 0,59 , CRP 0,3, dan IT Ratio 0,08. Cedera internal tidak terjadi ditandai dengan tidak ada ikterik, tidak ada kejang, bilirubin total $4,26 \mathrm{mg} / \mathrm{dl}$, bilirubin direk $0,07 \mathrm{mg} / \mathrm{dl}$, bilirubin indirek 4,19 mg/dl, LT dihentikan pada hari perawatan ke-20. Nutrisi adekuat ditandai berat badan minggu pertama 1225 gram (turun 235 gram atau 16\% dari berat lahir). Berat badan mencapai berat lahir kembali pada usia 14 hari (1400 gram). Follow up peneliti pada minggu ke-3 mendapatkan hasil Berat badan bayi 1700 gram pada usia kronologis $32+5$. Minggu ke-4 reflek hisap bayi baik pada usia kronologis $33+5$, nilai EFS 10 , dan OGT dilepas, bayi minum per oral. Bayi pulang pada usia kronologis34+1. Bayi kontrol pada tanggal 19 Mei 2014 (usia kronologis $35+5$ ), berat badan 2300 gram.

\section{Kasus 2.}

Bayi Ny "D.H” lahir prematur UG 30 minggu pada tanggal 10 Maret 2014, sesuai masa kehamilan (SMK) dengan berat lahir 1000 gram. Usia kronologi bayi pada saat peneliti memulai asuhan keperawatan 33 minggu. Berat sekarang 1030 gram. Hasil Echocardiogram pada tanggal 27 Maret 2014 menunjukkan PDA tiny non significant hemodinamici. Hasil USG kepala pada tanggal 27 Maret 2014 menunjukkan resolving IVH grade I kiri. Tatalaksana bayi Ny "D.H": buble CPAP dengan $\mathrm{FiO}_{2}$ $21 \%$ dan peep 5 .

Tropicognosis yang muncul adalah: (1) gangguan perfusi jaringan; (2) gangguan pola nafas; (3) gangguan termoregulasi; (4) resiko nutrisi kurang dari kebutuhan tubuh; (5) gangguan proses keluarga.

Implementasi keperawatan memonitor tanda penurunan perfusi jaringan (CRT memanjang, akral dingin), memonitor pernafasan dan alat bantu nafas (frekuensi pernafasan, saturasi oksigen, apnea,dan 
sianosis), menjaga suhu lingkungan bayi tetap hangat (inkubtor, nest, linen, tangan perawat yang kontak dengan bayi), melibatkan keluarga dalam perawatan. Peneliti memberikan albumin 4cc + lasix 1mg sesuai pragram. Nutrisi peroral untuk menjaga mukosa pencernan ASI $4 \times 1 \mathrm{ml}$ sesuai program. Nutrisi parenteral diberikan sesuai program.

Evaluasi asuhan keperawatan mendapatkan hasil perfusi jaringan adekuat, tidak ada apnea, tidak ada instabilitas suhu, berat badan 1095 gram meningkat 65 gram selam 5 hari atau 12 gram/hari.

\section{Kasus 3.}

Bayi ny"S.K" perempuan, lahir prematur 36 minggu, sesuai masa kehamilan, dengan berat lahir 2190 gram. Peneliti mulai memberikan asuhan keperawatan pada usia 2 hari. Usia 1 hari telah minum $8 \times 22 \mathrm{ml}$, kemudian usia dua hari muntah dan kuning grade I skala Kreamer. Reflek hisap baik, skor EFS 8. Tatalaksana bayi "S.K": blind light terapi, PG2
9,1 ml/jam, lipofundin $0,9 \mathrm{ml} / \mathrm{jam}$, ASI $8 \times 3 \mathrm{ml}$, CPAP $\mathrm{FiO}_{2} 21 \%$ peep 5.

Tropicognosis yang muncul adalah sebagai berikut: (1) gangguan pola nafas, (2) resiko perfusi jaringan tidak efektif, (3) gangguan termoregulasi, ganggun nutrisi kurang dari kebutuhan tubuh, (5) gangguan proses keluarga. Telah dilakukan implementasi: memonitor tanda penurunan perfusi jaringan (CRT memanjang, akral dingin), memonitor pernafasan dan menyesuaikan dengan alat bantu nafas buble CPAP (frekuensi pernafasan, saturasi oksigen, apnea,dan sianosis, $\mathrm{FiO}_{2}$ dan peep), menjaga suhu lingkungan bayi tetap hangat (inkubtor, nest, linen, tangan perawat yang kontak dengan bayi), melibatkan keluarga dalam perawatan, memonitor hasil laboratorium (marker infeksi, bilirubin, albumin). Evaluasi keperawatan mendapatkan hasil retraksi dada menghilang pada usia 4 hari sehingga CPAP dilepas, tidak ada apnea, tidak ada desaturasi, perfusi jaringan adekuat, tidak ada 
instabilitas suhu tubuh, reflek hisap baik, skor EFS 8, Berat badan pada usia satu minggu pertama 2050 gram turun 140 gram atau $6,3 \%$.

\section{Kasus 4.}

Bayi Ny 'D' lahir prematur pada usia 36 minggu gestasi, berat lahir 2215 gram sesuai masa kehamilan. Bayi dirawat dengan diagnosa medis sepsis neonatorum awitan dini. Riwayat ketuban pecah $>24$ jam, ibu mengalami keputihan pada saat hamil. Riwayat instabilitas suhu (hipotermi: $\quad 36,4^{\circ} \mathrm{C}$ ). Peneliti mulai merawat bayi Ny ' $\mathrm{D}$ ' ketika usia bayi mencapai $36+6$ dengan berat badan 1990 gram. Reflek hisap baik.Penatalaksanaan bayi Ny 'D'PG2 8,3ml/jam, D10+ca 4,1ml/jam, IL 20\% 1,4 ml/jam . Tropicognosis yang muncul: (1) resiko ketidakefektifan perfusi jaringan, (2) gangguan termoregulasi, (3) Resiko infeksi (lanjut), (4) ketidakseimbangan nutrisi kurang dari kebutuhan, (5) Gangguan proses keluarga. Peneliti telah melakukan implementasi keperawatan: (1) memonitor CRT, frekuensi nadi, frekuensi pernafasan, saturasi oksigen, suhu akral, loading $\mathrm{NaCl}$ 0,9\% 20 cc 1 kali, tranfusi PRC $20 \mathrm{cc} / \mathrm{kg}, 40 \mathrm{cc}$; (2) mengukur suhu tubuh bayi, dan menjaga suhu lingkungan bayi tetap hangat (inkubator, linen, nest, tangan perawat yang menyentuh bayi); (3) memonitor dan mengganti infus setiap 3 hari atau bila bengkak, memberikan terapi antibiotik sesuai program, memonitor marker infeksi (leukosit, IT ratio, CRP, dan prokalsitonin) dan nilai bilirubin total-direk-indirek, cuci tangan sebelum dan sesudah kontak dengan bayi-lingkungan bayiproduk cairan bayi; (4) mengkaji reflek hisap, memonitor toleransi minum bayi, menimbang berat badan bayi, memberikan terapi nutrisi sesuai program: enteral tropic feeding $8 \times 1 \mathrm{ml}$, nutrisi parenteral PG2-IL20\%$\mathrm{D} 10 \%+\mathrm{Ca}$; (5) Melibatkan keluarga dalam perawatan.

Peneliti melakukan evaluasi setelah 2 minggu perawatan. Hasil evaluasi menunjukkan perfusi 
jaringan efektif, tidak ada instabilitas suhu, bayi masih mengalami infeksi (leukosit $9550 / \mu \mathrm{L}, \quad$ IT ratio 0,8 , Prokalsitonin 1,21ng/ml), nutrisi adekuat toleransi minum $8 \times 15 \mathrm{ml}$ per oral baik (tidak ada muntah, kembung, saturasi oksigen stabil selama minum per oral), berat badan 2035 gram meningkat 15,2 gram per hari.

\section{Pembahasan}

Minum per oral merupakan proses yang sangat komplek pada bayi prematur karena melibatkan koordinasi pernafasan dengan otot oro motor untuk menghisap dan menelan. Reflek menelan mulai muncul usia gestasi 15 minggu dan reflek hisap berkembang pada usia gestasi 22-24 minggu. Koordinasi pusat pernafasan untuk menghisap-menelanbernafas terjadi pada usia gestasi 28 minggu tetapi masih beresiko mengalami kegagalan koordinasi. Kegagalan koordinasi meningkatkan resiko aspirasi pada bayi prematur. Koordinasi dapat dinilai dengan menggunakan EFS assesment.
Bayi siap minum per oral pada usia gestasi 32-34 minggu (Breton \& Steinwender, 2008; Jones, 2012).

Perbedaan usia gestasi terlihat pada kelima kasus kelolaan. Kasus 1 lahir pada usia gestasi 29 minggu, kasus kedua 30 minggu, kasus ketiga 36 minggu, kasus keempat 36 minggu, dan kasus kelima 33 minggu. Kelima bayi prematur lahir pada usia gestasi $>28$ minggu sehingga mampu mengkoordinasikan pernafasan dengan proses menghisap dan menelan tetapi masih beresiko terjadi kegagalan koordinasi. Reflek menghisap pada kasus ketiga dan keempat baik (usia gestasi 36 minggu) sedangkan reflek hisap lemah pada kasus pertama, kedua dan kelima (29, 30, dan 33 minggu gestasi). Reflek hisap bayi kasus 1 baik pada usia kronologis $33+5$, dibuktikan dengan nilai EFS 10. Kemampuan minum bayi baik sehingga OGT dilepas dan bayi minum per oral. Skor EFS 10 menunjukkan bahwa bayi Ny S mempunyai kecukupan energi untuk menyusu dan kecil resiko 
aspirasi. Upaya untuk mengurangi resiko aspirasi dengan memberikan minum per OGT.

Sistem pencernaan juga berfungsi sebagai sistem pertahanan tubuh. Bayi prematur mengalami penurunan sekresi imunoglobulin A yang melindungi lapisan mukosa lumen usus. Imaturitas menyebabkan rendahnya enzim proteolitik pankreas, enterokinase, sehingga menekan hidrolisis kuman. Kuman yang tidak terhidrolisis akan mengeluarkan toksin. Toksin akan lama berada di dalam lumen usus karena bayi prematur mengalami dismotilitas intestinal.

Penurunan sekresi imunoglobulin A, enterokinase, dan dismotilitas intestinal meningkatkan resiko kerusakan jaringan yang memicu terjadinya NEC (Josef, 2007; Gurllet, Stoll, dan Cotten, 2006). NEC terjadi pada kasus kelima dibuktikan dengan hasil foto rontgen abdomen, dan C-reactif protein (CRP) meningkat (CRP 0,6). Dismotilitas akan meningkatkan waktu transit makanan dan toksin sehingga perlu feeding yang aman. ASI merupakan pilihan utama untuk feeding bayi aterm, prematur, dan bayi sakit. ASI mengandung Ig A, Ig G, dan Ig M. Resiko NEC meningkat 6-10 kali lebih tinggi pada bayi yang menggunakan susu formula. Tropic feeding dapat mengurangi resiko NEC. Metode tropic feeding dapat dilakukan dengan OGT. Volume tropic feeding bervariasi mulai dari $\quad 0,1 \quad \mathrm{~s} / \mathrm{d} \quad 24 \mathrm{ml} / \mathrm{kg} / \mathrm{hari}$ (Gomela, 2009).

Kasus kelima mendapat nutrisi per OGT dengan Volume feeding mulai $2 \times 1$ cc ASI pada awal pemberian kemudian meningkat $4 \times 1$ cc. Ig A dari ASI membantu memperbaiki membran mukosa intestinal sehingga meminimalkan kontak toksin bakteri dengan membran mukosa. Protein ASI akan menstimulasi sekresi enzime proteolitik pankreas. Protein kuman akan ikut terhidrolisis oleh enzime proteolitik pankreas sehingga mengurangi toksin. Peningkatan volume di dalam intestinal akan 
menstimulasi

gerak

peristaltik/motilitas usus sehinga

toksin di dalam lumen dapat dimobilisasi keluar tubuh.

Feeding tidak memperburuk

NEC. Perbaikan NEC dibuktikan

dengan foto rontgen abdomen.

Penambahan berat badan kasus

kelolaan 1 dan keempat adekuat

karena $>15 \mathrm{gr} /$ hari. Berat badan

kasus keempat meningkat 15,2

gr/hari. Pertumbuhan Bayi Ny D

dibuktikan dengan meningkatnya

berat badan dari 1990 menjadi

2035 gram. Bayi Ny D mulai

minum peroral dan mampu

mentolerir nutrisi enteral ASI

sampai dengan mencapai volume

$8 \times 15 \mathrm{ml}$ (120 ml/hari). Toleransi

minum Bayi Ny D

dimanifestasikan dengan tidak ada kembung dan tidak ada muntah.

\section{Kesimpulan}

Model konservasi Levine dapat diaplikasikan untuk merawat bayi prematur.

\section{Daftar Pustaka}

Josef, N. (2009). Gastrointestinal development and meeting
Alligood, M. R, \& Tomey, A. M. (2006). Nursing theory: Utilization \& aplication. St Louis : Mosby

Amendolia, B. (2011). An integrative review of feeding intolerance in preterm infants: State of the sciensce. Clinical Scholars Review. 4(2).82-90. Doi: $10.1891 / 1939-2095$

Breton, S., Steinwender, S. (2008). Timing introduction and transition to oral feeding in preterm infants: Currnt trends and practice. Newborn Infant Nurs Review;8(3):153-159

Brodsky, D., \& Ouellette, M. A. (2008). Primary care of the premature infant. Philadelphia: Saunders

CSPEN. (2013). CSPEN guidelines for nutrition support in neonates. Asia Pacifik Jurnal Clinical Nutrition; 22(4):655-663

Gurllet, R., Stoll, B. J., Cotten, C. M. (2006). Association of $\mathrm{H} 2$ blocker theraphy and higher incidence of necrotizing enterocolitis in very low birth weight infant. Pediatrics; 117:eI37-42

Jones, L. R. (2012). Oral feeding readiness in the neonatal intensive care unit. Neonatal Network ;31(3): 148-155. Doi: $10.1891 / 0730-$ 0832.31.3.148

the nutritional needs of prematur infants. The American Journal of 
Clinical Nutritional; 85:629s -634s

Meleis, A. I. (2012) . Theoritical nursing developmen and progress. Philadelphia: Lipincott William \& Wilkins 